\title{
Gyrodactylus anguillae and Vibrio vulnificus infections affecting cultured eel, Anguilla anguilla
}

\author{
Mamdouh Yousif Elgendy*, Amany Mohamed Kenawy, Ahmed E Noor El-Deen
}

National Research Centre, Dokki, Giza, Egypt

*Corresponding author, e-mail: my.abdelaziz@nrc.sci.eg

\begin{abstract}
Gyrodactylus anguillae and Vibrio vulnificus are pathogens of critical significance in anguilliculture. Both agents were involved in mortalities affecting earthen pond cultured European eel, Anguilla anguilla, in Egypt during the period extended from June to September 2014. Moribund eels showed excessive slimy mucus and haemorrhages on the external body surface. All investigated eels were parasitized with the monogenean, Gyrodactylus anguillae. Majority of specimens $93.3 \%$ were concomitantly found to be infected with $V$. vulnificus. No other parasitic or bacterial infections were noticed in the investigated fish samples. V. vulnificus was detected in Gyrodactylus anguillae homogenates collected from diseased fish. Bacterial isolates were confirmed by polymerase chain reaction (PCR). G. anguillae were demonstrated in skin and gills histopathological sections. Varieties of circulatory, proliferative as well as degenerative changes were noticed in haemopoietic tissues. It was concluded that $G$. anguillae presumably enhanced eels vulnerability to $V$. vulnificus infections through providing portals of entry as well as acting as mechanical vectors.
\end{abstract}

Keywords: concurrent infections, European eel, monogenean, mortalities, vibrios

\section{Infecções por Gyrodactylus anguillae e Vibrio vulnificus afetam enguias criadas em cativeiro, Anguilla anguilla}

\section{Resumo}

Gyrodactylus anguillae e Vibrio vulnificus são patógenos de importância crítica em anguilliculture. Ambos os agentes estiveram envolvidos na mortalidade que afetam lagoa de barro enguia europeia, Anguilla anguilla, no Egito durante o período estendido de junho a setembro de 2014. enguias moribundos apresentaram-se com muco viscoso excessivas e hemorragias na superfície externa do corpo. Todas as enguias investigados estavam parasitados com o monogenético, Gyrodactylus anguillae. A maioria dos espécimes $93,3 \%$ foram concomitantemente considerados infectados com $V$. vulnificus. Não há outras infecções parasitárias ou bacterianas observadas nas amostras de peixes investigados. V. vulnificus foi detectado em Gyrodactylus homogeneizados anguillae coletados de peixes doentes. Os isolados bacterianos foram confirmadas por reacção em cadeia da polimerase (PCR). G. anguillae foram demonstrados em seções histopatológicas na pele e brânquias. Alterações circulatórias, alterações proliferativas, bem como degenerativas foram observadas em tecidos hematopoiéticas. Concluiu-se que $G$. anguillae presumivelmente reforça vulnerabilidade das enguias a infecções $V$. vulnificus através do fornecimento de vias de entrada, bem como atuando como vetores mecânicos.

Palavras-chave: Infecções simultâneas, enguia europeia, monogenético, organismos mortos, vibriões 


\section{Introduction}

Eel has long been considered a pivotal species for aquaculture industry worldwide. Eels are distributed globally in marine, brackish and freshwaters. Eel farming still relies entirely on wild seed supply since reproduction in captivity has not achieved at a commercial scale (FAO, 2014).

Recently, European eel has been listed as critically endangered on the IUCN red list of threatened species (Jacoby \& Gollock, 2014). The overfishing of glass eel, along with environmental pollution and other human activities, have all contributed to a significant decline in eel numbers over the last two decades (Nielsen \& Prouzet, 2008). Ultimately, reproduction of eel in culture has become a critical research area particularly with an increased interest to produce glass eels for a self-sustainable farming industry (Davidsen, 2012).

Eel diseases caused by parasitic and bacterial agents are along the prominent challenging pressures thought to impact eel farming industry all over the world (Jacoby \& Gollock, 2014). A vast array of microorganisms has been focused on as potential contributing factors (Esteve \& Alcaide, 2009; Haenen et al., 2010; Dangel et al., 2015). On the top of the critical pathogens list, Vibrio vulnificus is viewed as the most dangerous bacterial septicemia in eel farming. The disease occurs as epizootics of high mortalities causing massive economic losses particularly in immunocompromised stocks (Amaro et al., 1995; Dalsgaard et al., 1999; Marco-Noales et al., 2001).

It is widely accepted that a link between fish ectoparasites and bacterial infections coexist (Bandilla et al., 2006). Diverse opportunistic infections have been found to boost concomitantly or a consequence to numerous parasitic infestations (Busch et al., 2003; Pylkko et al., 2006). The pathways that can lead to such increased vulnerability might be relevant to; creation of entrance routes stemming from epidermal injuries induced by a parasite (Buchmann \& Bresciani, 1997) or via decreased host immunocompetence (Bowers et al., 2000), in addition to acting as vectors for infectious agents (Cusack \& Cone, 1986).

The present study aimed to investigate the parasitic as well as concomitant bacterial infections involved in eel mortalities cultured in earthen ponds within a farm located in Shatta Damietta Egypt, during the summer 2014. Further the study describes the histopathological responses in diseased fish.

\section{Material and Methods}

Area of study and fish sampling

During the period extended from June to September 2014, massive mortalities approached 65\% attacked European eel, Anguilla anguilla cultured within earthen ponds in a fish farm located in Shataa region at Damietta Egypt. These eels were caught from the Mediterranean Sea at El-Max region. The farm water salinity was $8 \%$. Mortalities started after two month of culture. Fish were fed on high protein diet $50 \%$, composed of commercial dry food mixed with freshly minced fish (2: 1).

Thirty A. anguilla specimens were collected randomly to determine the causative agents of disease. The average body weights of fish were $50 \pm 15 \mathrm{~g}$. Samples were transferred with a minimum time of delay within ice in isothermal boxes to Hydrobiology Department lab, National Research centre, Egypt to be investigated.

\section{Necropsy and parasitological examination}

Fish were visually inspected for presence of abnormalities and external parasites. Smears from skin mucus and a piece of gills tissue were microscopically examined for parasites. Furthermore, the body cavity of each eel was cut opened, and the internal organs including gasbladder were thoroughly investigated for macroscopically visible parasites. Fresh smears prepared from intestinal contents and blood were directly examined microscopically according to Haenen et al. (2010).

\section{Bacteriological examination}

Samples were aseptically obtained from liver, kidneys and spleen. Smears were cultured onto Tryptic soya agar TSA (Oxoid) and Thiosulfate citrate bile salt sucrose agar medium, TCBS, (Oxoid). The inoculated plates were incubated at $25^{\circ} \mathrm{C}$ for 24 to $48 \mathrm{~h}$. Bacterial colonies were collected from plates and re-streaked onto TSA 
for purification and identification.

Isolation of bacteria from collected parasites was carried out according to Madinabeitia et al. (2009). Three Gyrodactylus anguillae were randomly taken from each fish and processed as one group. Gills were removed with forceps and washed with saline $(0.85 \% \mathrm{NaCl})$ then homogenized together using a sterile plastic rod. The homogenates were serially 10 -fold diluted with saline and inoculated onto Tryptic soya agar TSA (Oxoid) as well as TCBS medium (Oxoid). The plates were incubated at $25^{\circ} \mathrm{C}$ for 24 to $48 \mathrm{hr}$.

Identification of isolates

Identification of all bacterial isolates from fish and ectoparasites was performed by studying the phenotypic and biochemical characteristics using both conventional and commercial API 20 E systems following the criteria described in Buller (2004).

\section{Molecular identification}

DNA from bacterial colonies was extractedusing Bacterial Genomic DNA extraction Kit (Fermentas, Vilnius, Lithuania) following the manufacturer's instructions. Concentration and purity of DNA samples were measured using a spectrophotometer (Konica Minolta, Tokyo, Japan). PCR was performed in $25 \mu \mathrm{l}$ volumes consisting of $5 \mu \mathrm{M}$ master mix, 100ng of genomic DNA template and 1 pMol of 165 rDNA specific primers, forward: 5'TCTAGCGGAGACGCTGGA3' and the rivers: 3'GCTCACTTTCGCAAGTTGGCC5' according to kim \& Jeong (2001).

The reaction started with initial denaturation for 5 minutes at $94^{\circ} \mathrm{C}$ followed by 30 cycle of 30 -seconds denaturation at $94^{\circ} \mathrm{C}, 30$ second annealing at $54^{\circ} \mathrm{C}, 72^{\circ} \mathrm{C}$ for 30 second and a final extension at $72^{\circ} \mathrm{C}$ for 10 minutes. The amplification products were analyzed by running through $1.0 \%$ agrose gel electrophoresis, stained with ethidium bromide and visualized under UV trans-illumination system. A DNA ladder with 100bp increment (Fermentas, Vilnius, Lithuania) was used as a molecular weight marker according to Moustafa et al. (2014).
Histopathological examination

Tissue specimens from gills, liver, spleen and kidneys were collected from infected fish for histopathological studies. Samples were fixed in Davidson's fixative for $48 \mathrm{~h}$ then transferred into ethanol, embedded in paraffin and sectioned. Tissue sections were processed and stained with Hematoxylin \& Eosin (H \& E) then examined by light microscopy according to Bancroft \& Gamble (1996).

\section{Results}

\section{Clinical picture}

Investigated eels showed excessive slimy mucus and haemorrhages on the external body surface. Reddens of the mouth and head region were also common. Gills were swollen, pale to grayish with presence of excessive amount of mucus. Injures and erosions are evident. Additionally, few cases noticed ulcers on the external body surface. The anal opening was inflamed, redden and occasionally protruding. Internally, congestion and enlargement of liver as well as gas bladder were prominent (Figure 1).

Parasitological examination

All investigated eel samples were parasitized with the monogenean, Gyrodactylus anguillae Ergens, 1960 on the skin and gills. The intensity was (7 - 21) parasite / per fish. No other concomitant parasitic infestations were detected in moribund eels.

\section{Bacteriological examination}

Majority of moribund eel specimens 93.3

$\%$ were found to be infected with $\vee$. vulnificus. No other bacterial infections were detected in investigated specimens. $V$. vulnificus was also retrieved from all $G$. anguillae homogenates. The full phenotypic and biochemical characteristics of $V$. vulnificus isolates are illustrated in tablel.

\section{Molecular identification}

V. vulnificus isolates obtained from both G. anguillae homogenates and moribund eels were confirmed by polymerase chain reaction (PCR). The specific $V$. vulnificus primers yielded definite $273 \mathrm{bp}$ amplicons identical for the size of the target gene sequence in all strains tested (Figure 2). 


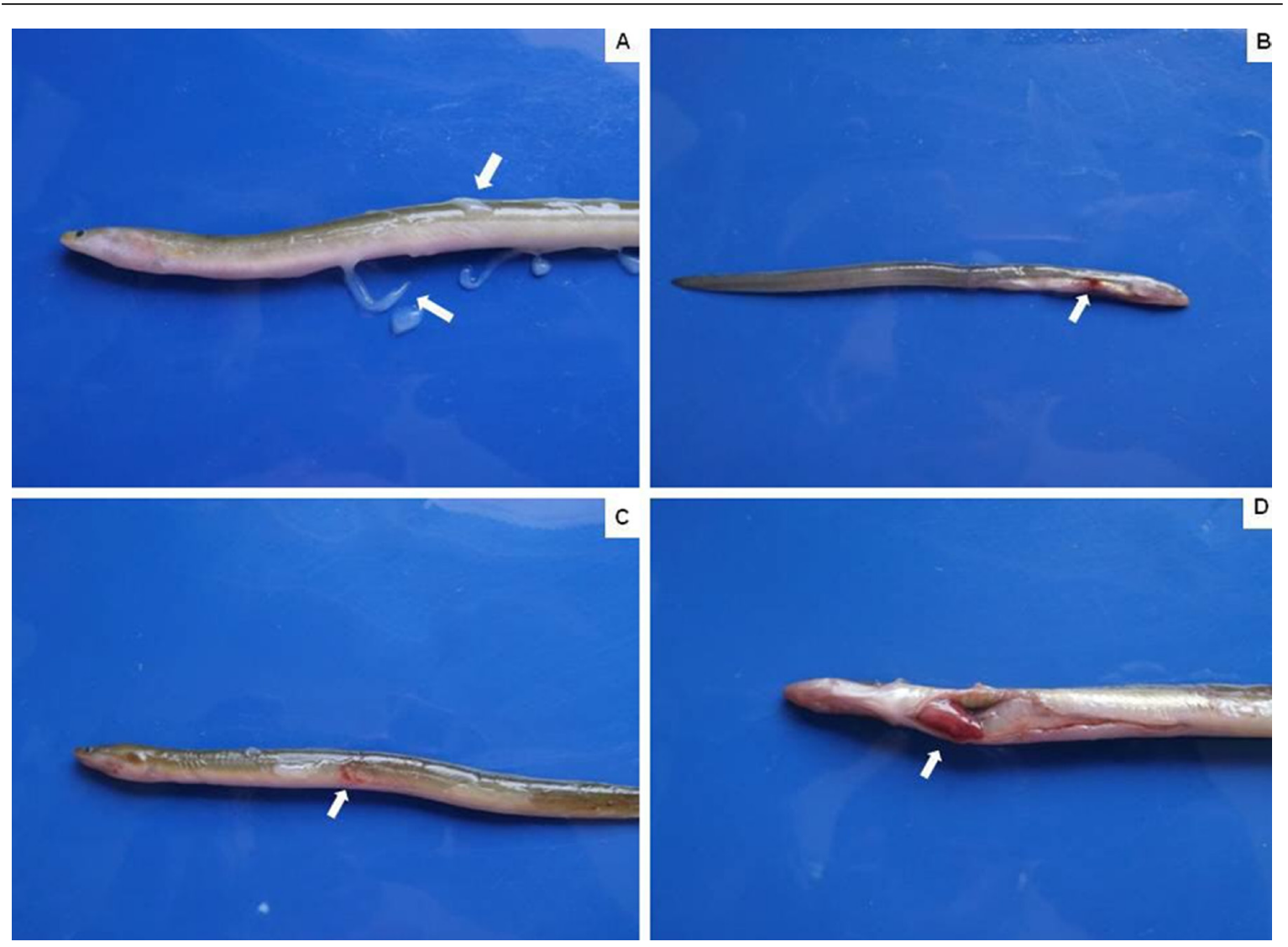

Figure 1. A. Anguilla anguilla showing extensive secretion of slimy mucus on the external body surface, B. Anguilla anguilla showing haemorrhages on the external body surface, C. Anguilla anguilla showing ulcer on the external body surface, and D. Anguilla anguilla showing congestion and enlargement of liver.

Table 1. Phenotypic and biochemical characteristics of retrieved $V$. vulnificus isolates

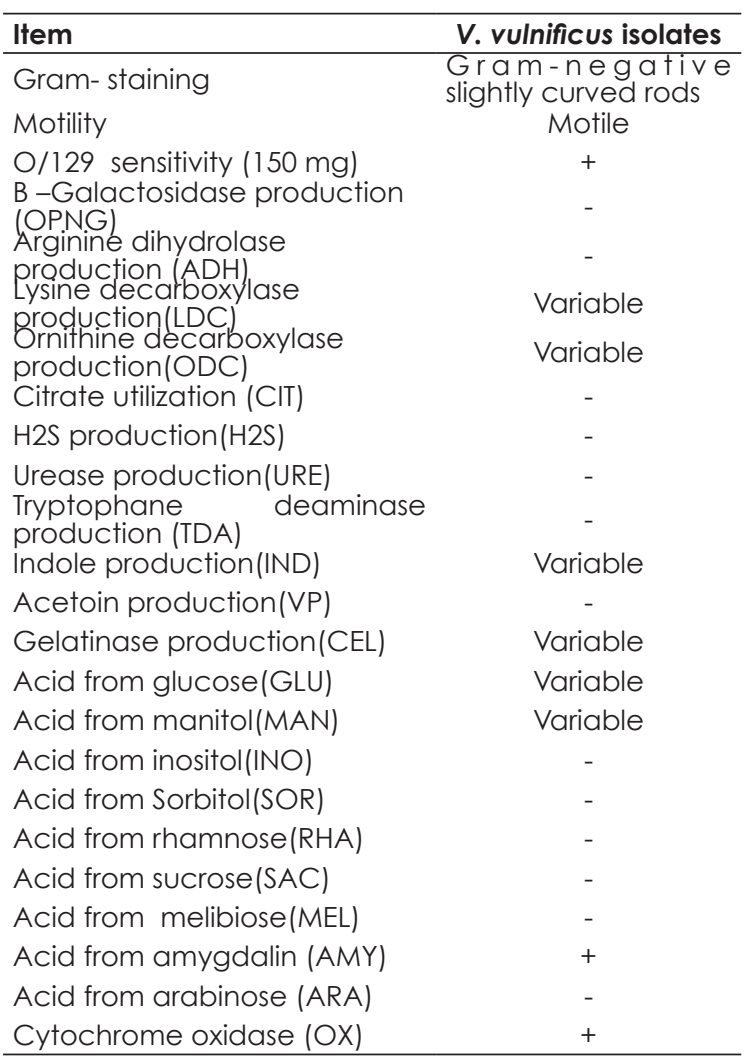

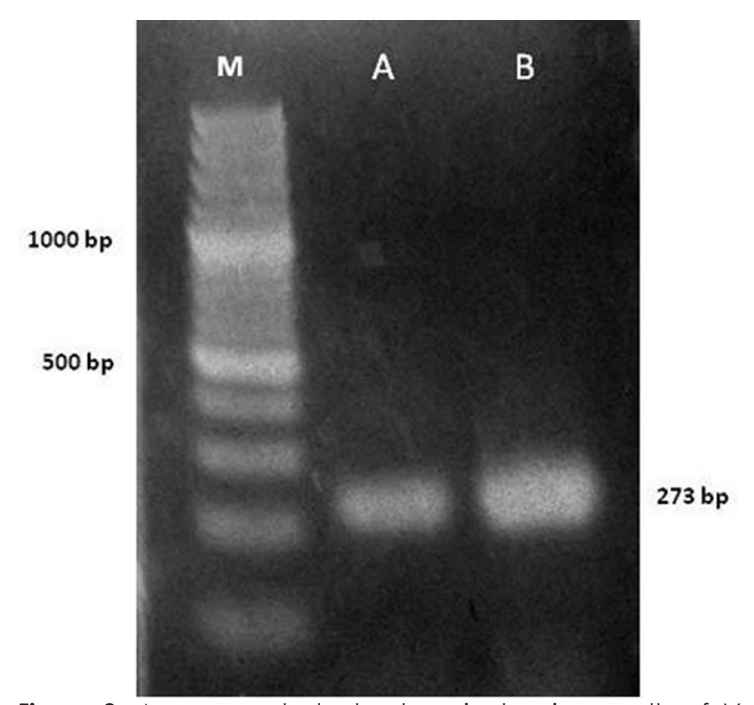

Figure 2. Agarose gel electrophoresis showing results of $\mathrm{V}$. vulnificus PCR products. M, 100 bp molecular weight marker, Lane A \& B, V. vulnificus. Numbers above indicates the size of corresponding bands (bp). 
Histopathological examination

Varieties of histopathological alterations were detected in sections prepared from investigated eel specimens. Sections of $G$. anguillae were seen in between gill lamellae (Figure 3. A, B). Hyperplasia of the epithelial lining the secondary gill lamellae with lamellar fusion were evident (Figure 3. C). Additionally, severe congestion of lamellar blood vessels in concert with telangiectasis and edema were common in the secondary gill lamellae. Moreover, accumulations of inflammatory cells as well as necrotic changes at attachment sites of parasites were frequently detected (Figure 3. C, D).

Rigorous histopathological alterations were also detected in skin sections. Widespread dermatitis, dermal edema with hyper activation as well as hypertrophy of mucous secreting cells were evident (Figure 3. E). Furthermore, extensive leukocytic infiltrations in conjunction with melanophores proliferation were commonly noticed (Figure 3. F). Hemorrhages and dilatation of blood capillaries also were seen in subepidermal layers. Sections of parasitic larvae appeared in between muscle bundles with destruction in muscular layers (Figure 3. G, H).

Liver showed variety of circulatory and degenerative changes. Hemorrhages, congestion as well as hyperplasia in the wall of hepatic blood vessels were noticed regularly (Figure 4. A). Extensive vacuolar degeneration and necrosis of hepatocytes were commonly detected. Some cases reveled, dilatation of intercellular spaces with infiltration of chronic inflammatory cells in between hepatic parenchyma (Figure 4. B).

The histopathological alterations were destructive in kidneys. Widespread hemorrhages and hyperplasia in the wall of renal blood vessels were characteristic. Severe degenerative and necrotic changes were common in the hematopoietic tissue as well as tubular epithelial cells. Majority of cells noticed clear signs of kariopicnosis and kariolysis (Figure 4. D).

\section{Discussion}

The evolution of intensive aquaculture activities created perfect circumstances for the spread of numerous fish pathogenic agents causing substantial economic losses (Elgendy, 2013; Moustafa et al., 2014; Elgendy et al., 2015a). Infectious diseases have long been considered as critical constraints in aquaculture industry all over the world (El-Gendy, 2007; Austin \& Austin, 2012).

V. vulnificus and Gyrodactylus species are serious pathogens in eel farming (Borgsteede et al., 1999; Esteve \& Alcaide, 2009). V. vulnificus has caused numerous epizootic outbreaks and massive mortalities in anguilliculture worldwide (Biosca et al.,1991; Dalsgaard et al., 1999; Marco-Noales et al., 2001). Regionally, it was also retrieved from mortalities affecting many other fish and shellfish in Egypt (Elgendy et al., 2015b; Moustafa et al., 2015).

Gyrodactylus species are also renowned pathogens affecting diverse eel species worldwide (Hayward et al., 2001). Along these gyrodactylids, G. anguillae Ergens 1960, has been reported as a devastating pest in eel farming with expanding global range (Ogawa \& Egusa 1980; Mellergaard \& Dalsgaard 1987; Hayward et al., 2001).

In this study, the concomitant infections of G. anguillae Ergens, 1960 and V. vulnificus were found to be the potential causes of eels mortalities in the investigated farm. All examined eel specimens were infested with $G$. anguillae. Moreover, majority of samples $93.3 \%$ were concurrently infected with $V$. vulnificus suggesting a potential role for theses ectoparasitic infestations in enhancing vibriosis in cultured eels.

Phenotypically, retrieved $V$. vulnificus isolates from eels as well as $G$. anguillae homogenates were Gram-negative slightly curved rods in agreement with (Buller, 2004). All isolates were sensitive to $0 / 129$ vibriostatic agent. Isolates were confirmed by polymerase chain reaction (PCR). Definite 273 bp amplicons were produced in all bacterial strains tested in conformity with (Moustafa et al., 2015).

Successful transmission of pathogen is a critical step in the pathway of infectious disease outbreaks attacking cultured fish (Elgendy et al., 2015a). Field results supported the hypothesis that water is the main vehicle for transmission of vibrio epizootics affecting farmed eel (Amaro et al., 1995). The primary portals of $V$. vulnificus 

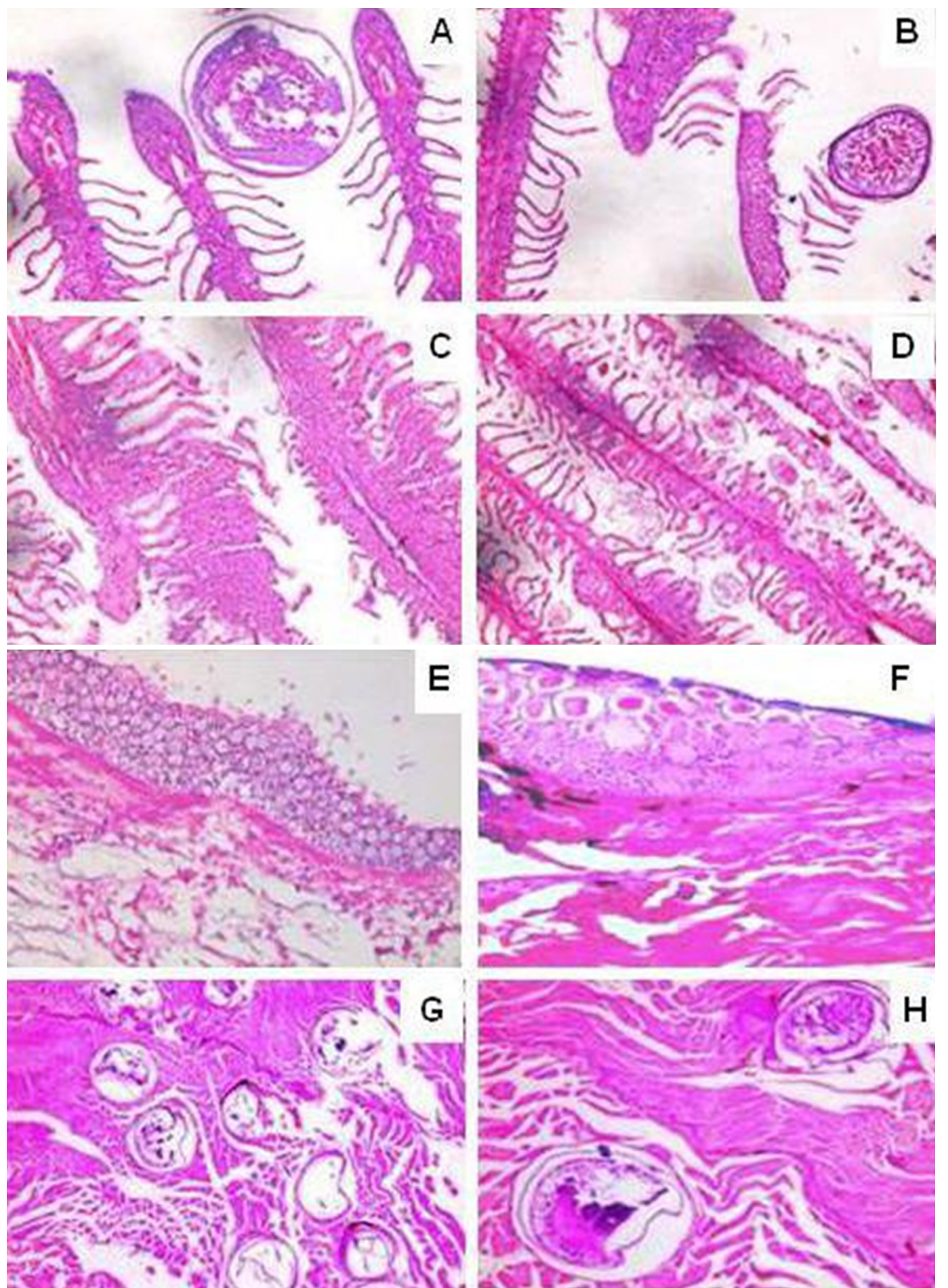

Figure 3. A, B. Gills of Anguilla anguilla showing parasitic sections in between the secondary lamellae (H\&E,X 400), C. Gills of Anguilla anguilla showing hyperplasia and proliferation of epithelial cells lining the secondary lamellae with fusion of secondary lamellae (H\&E,X 200), D. Gills of Anguilla anguilla showing sections of Gyrodactylus anguillae and necrotic changes at parasite attachment sites (H\&E,X400), E. Skin of Anguilla anguilla showing dermatitis, dermal edema, hyper activation and hypertrophy of mucous secreting cells (H\&E,X200), F. Skin of Anguilla anguilla showing leukocytic infiltrations and melanophores proliferation (H\&E,X400), $\mathbf{G}$ and $\mathbf{H}$. Skin of Anguilla anguilla showing parasitic larvae with extensively destroyed muscle bundles (H\&E,X200\&X400). 

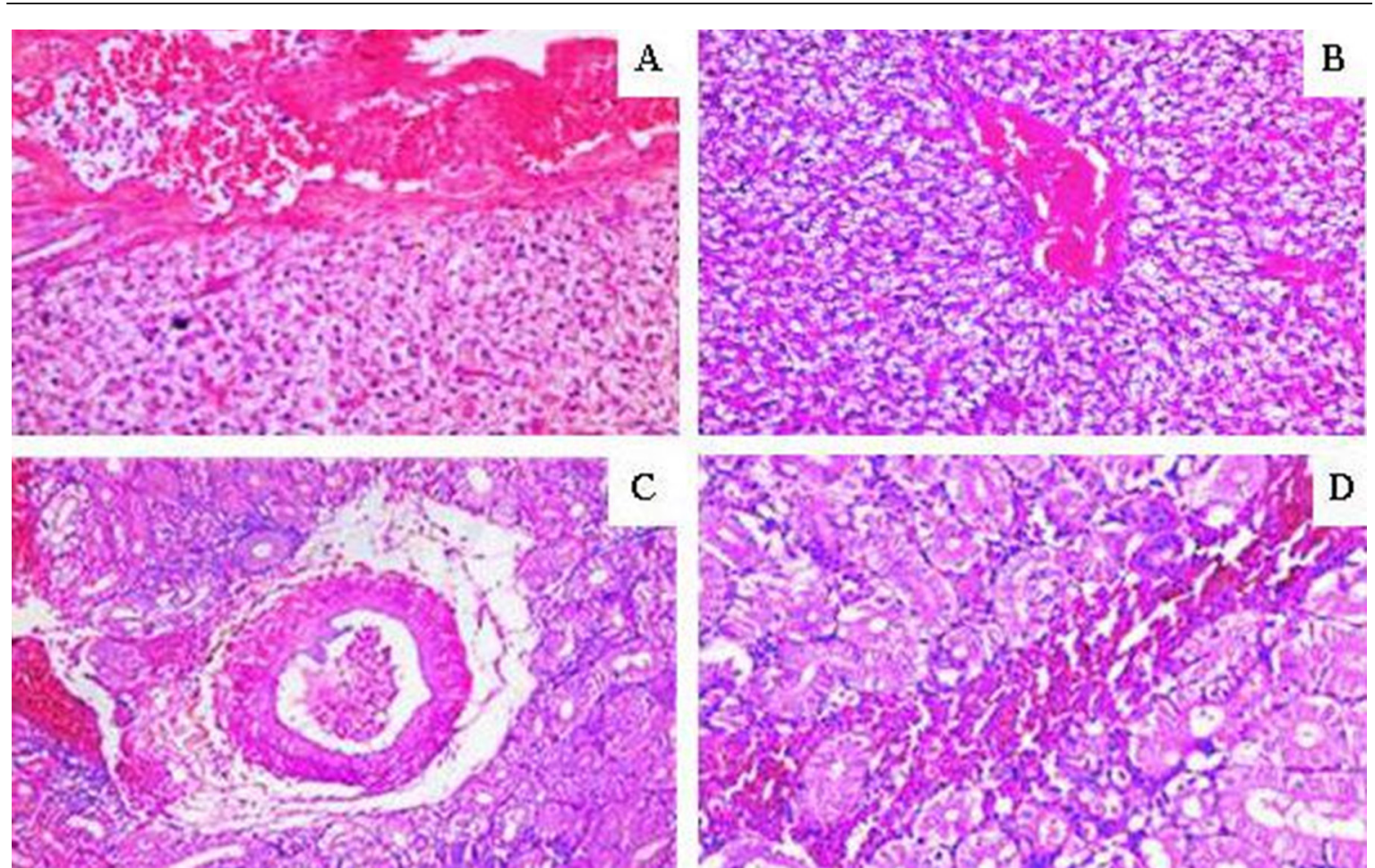

Figure 4. A. liver of Anguilla anguilla showing severe congestion, hemorrhages and hyperplasia in the wall of hepatic blood vessels, (H\&E, X200), B. liver of Anguilla anguilla showing severe vacuolar degeneration and congestion (H\&E, X 200\& X400), C. Kidney of Anguilla anguilla showing extensive hemorrhages and hyperplasia in the wall of renal blood vessels, (H\&E, X 200) and D. Kidney of Anguilla anguilla showing extensive hemorrhages, degenerative and necrotic changes in the tubular epithelial cells as well as hematopoietic tissue with some cells showed clear signs of kariopicnosis and kariolysis, (H\&E, X200).

entry are via gills, fins and the anus. This pathogen when released into water not only adhere to eel surfaces but also multiply forming a biofilm enabling cells to survive for long periods on fish body as competent reservoirs (Marco-Noales et al., 2001).

Fish ectoparasites including Gyrodactylus species, are known to enhance numerous fish opportunistic infections. They strongly attach themselves to fish gills, fins and skin. Their movement from one location to another on fish cause integumental breaks as well as mechanical injuries to the epithelium (Cone \& Odense, 1984). These injuries are effective entrance roots consequently; enhance the transmission competence of pathogens making fish with Gyrodactylus more susceptible to secondary bacterial infections (Shoemaker et al., 2008).

Many studies have reported augmented bacterial infections concomitantly with fish parasitic infestations. Evans et al. (2007) declared that parasitism of channel catfish fry, Ictalurus punctatus, with Tricodina species increased catfish vulnerability to streptococcal disease. Mechanical injuries induced by these parasites boosted infection potentials. Moreover, Bandilla et al. (2006) demonstrated that co-infections of Argulus coregoni with $F$. columnare enhanced rainbow trout susceptibility to bacterial pathogen compared with single infections since mortalities were significantly higher and the onset of disease occurred earlier in fish with concomitant infections. Skin damage created by Argulus coregoni feeding activities supported bacterial attachment. Additionally, Pylkkö et al. (2006) reported that fish infected with digenetic trematode, Diplostomum spathaceum, was more vulnerable to Aeromonas salmonicida infections than others without parasitic infestations.

One major critical role relevant to fish ectoparasites in the pathway of fish infections is that, majority of these parasites could be powerful mechanical vectors, potentially transfer pathogens from infected to healthy fish (Nylund et al. 1993, 1994; Xu et al., 2007). They feed on host mucus, tissue and blood consequently transmit pathogens from diseased to healthy fish (Gustafson et al., 2005). The theory has been highlighted in the current study by isolation of $V$. vulnificus from $G$. anguillae homogenates collected from moribund eels suggesting potential pathway for vibrios infections. Infected 
materials are thought to be ingested while Gyrodactylus feeds on fish blood and tissues (Buchmann \& Lindenstrøm 2002). Cusack \& Cone (1985) elucidated using electron microscopy the presence of bacteria in close association with monogenetic trematodes and suggested a vectoring role for these parasites.

The invading parasites can also indirectly potentiate bacterial infections through devastating the host immune defense mechanisms (Bowers et al., 2000). Even fish with low external parasite burdens can have elevated cortisol levels, causing immunosuppression consequentially render host fish more susceptible to secondary infections. The severe debilitating conditions as well as damaged skin commonly noticed in affected stocks likely disrupt the osmoregulatory capacity worsening the case (Buchmann, 2012).

Many pathogenic and commensal microorganisms also use mucus glycoproteins as receptors for attachment (Easy \& Ross, 2009; Estensoro et al., 2013). Studies have demonstrated that $V$. vulnificus possess a specific binding to fish mucus and the degree of adhesion boosts with excess mucus, particularly in encapsulated vibrio strains. Furthermore, V. vulnificus isolates have great ability to resist the antimicrobial activity of eel mucus in in-vitro experiments (Amaro et al., 1995). Therefore surplus mucus secretions induced by $G$. anguillae potentially accelerated establishment of vibrios in the studied farm.

Additionally, ectoparasites can change some biochemical characteristics of fish mucus (Estensoro et al., 2013). The incompetence of mucus antagonistic effects against pathogenic microorganisms as well as ability of vibrios to utilize mucus as a carbon source, favor their settlement on fish surfaces (Bordas et al., 1996). Subsequently, attached bacteria develop a biofilm which enhances genes transfer between bacterial strains and convert avirulent strains into extremely potent pathogens (Montgomery \& Kirchman, 1994; Benhamed et al., 2014).

The noticed histopathological alterations were indicative for interactions between invading G. anguillae, V. vulnificus and eels. Parasitic invasion of fish epidermis elicits inflammatory reactions involving several cell types (Buchmann
\& Lindenstrøm, 2002). The widespread dermatitis, extensive leukocytic infiltrations as well as melanophores proliferation were frequently detected. Infiltrated leucocytes secrete cytokines and other immunoactive compounds in attempt to control infection (Estensoro et al., 2013). The hyper activity of goblet cells in skin and gills indicates a primary host control mechanism against pathogen burden in the outer mucus layer through shedding and renewal of the mucus secretions (Estensoro et al., 2013). The proliferation of the lining epithelium may be relevant to the severe irritation caused by attachment and feeding activities of monogenetic trematodes on fish tissues in conformity with similar cases (Dezfuli et al., 2007).

Varieties of circulatory, degenerative changes were also detected in hemopoietic tissues. Destruction of critical components of both circulatory and immune systems by $\vee$. vulnificus extracellular products may be incriminated in the detected pathological alterations (Elgendy, 2013). It has been documented that $V$. vulnificus produce diversity of destructive extracellular products including elastase, protease, hemolysin, collagenase, DNase, lipase, phospholipase, mucinase, chondroitin sulfatase, hyaluronidase and fibrinolysin (Wright \& Morris, 1991; Al-Assafi et al., 2014). The produced exotoxins were found to be lethal for eels and the crude extracts of these extracellular products can induce classical vibriosis in fish when injected intraperitoneally (Biosca \& Amaro, 1996). One more major virulence factor of $V$. vulnificus is the capsular polysaccharides that protect bacteria from bactericidals and phagocytosis. Additionally, various iron uptake systems, including siderophore production and the ability to use hemin and hemoglobin as iron sources potentiate infections (Amaro et al., 1994; Shin et al., 2005).

\section{Conclusions}

The results extracted from the current study support the link between fish vibriosis and Gyrodactylosis. The results clarified that $G$. anguillae presumably enhanced eels vulnerability to $V$. vulnificus infections through providing portals of entry as well as acting as mechanical vectors. 


\section{References}

Al-Assafi, M., Abd Mutalib, S., Abd Ghani, M. Aldulaimi, M. 2014. A Review of Important Virulence Factors of Vibrio vulnificus. Current Research Journal Biological Sciences 6: 76-88.

Amaro, C., Biosca, E.G., Fouz, B., Alcaide, E., Estev, E.C. 1995. Evidence that water transmits Vibrio vulnificus biotype 2 infections to eels. Applied and Environmental Microbiology 61: 1133-1137.

Amaro, C., Biosca, E.G., Fouz, B., Toranzo, A.E., Garay, E. 1994. Role of iron, capsule, and toxins in the pathogenicity of Vibrio vulnificus biotype 2 for mice. Infection and Immunity 62: 759-763.

Austin, B., Austin, D.A. 2012. Bacterial Fish Pathogens, Disease of Farmed and Wild Fish. 5th edn. Springer, Media, Germany. 652 p.

Bancroft, J.D., Gamble, M. 1996. Theory and practice of Histological techniques, $4^{\text {th }}$ edition. Chruchil living stone, Edinburgh, Scotland. 766 p.

Bandilla, M., Valtonen, E.T., Suomalainen, L. R., Aphalo, P.J., Hakalahti, T. 2006. A link between ectoparasite infection and susceptibility to bacterial disease in rainbow trout. International Journal of Parasitology 36: 987-991.

Benhamed, S., Guardiola, F.A., Mars, M., Esteban, M. 2014. Pathogen bacteria adhesion to skin mucus of fishes. Veterinary Microbiology 171:1-12.

Biosca, E.G., Amaro, C. 1996. Toxic and enzymatic activities of Vibrio vulnificus biotype 2 with respect to host specificity. Applied and Environmental Microbiology 62: 2331-2337.

Biosca, E.G., Amaro, C., Esteve, C., Alcaide, E. Garay, E. 1991. First record of Vibrio vulnificus biotype 2 from diseased European eel Anguilla anguilla L. Fish Diseases 4: 103-109.

Bordas, M.A., Balebona, M.C., Zorrilla, I., Borrego, J.J., Morinigo, M.A. 1996. Kinetics of adhesion of selected fish-pathogenic Vibrio strains of skin mucus of gilt-head sea bream (Sparus aurata L.). Applied and Environmental Microbiology 62: 3650-3654.

Borgsteede, F.H., Haenen, O.L., DeBree, J., Lisitsina, O.I. 1999. Parasitic infections of European eel, Anguilla anguilla, in the Netherlands. Helminthologia 36: 251-260.

Bowers, J.M., Mustafa, A., Speare, D.J., Conboy, G.A., Brimacombe, M., Sims, D.E., Burka, J.F. 2000. The physiological response of Atalntic salmon, Salmo salar L., to a single experimental challenge with sea lice, Lepeophtheirus salmonis. Fish Diseases 23: 165-172.

Buchmann, K. 2012. Gyrodactylus salaris and gyrodactylus derjavinoides. In: Woo, T.K.,
Buchmann, K. eds. Fish parasites: pathobiology and protection. CAB International, Cambridge, UK.

Buchmann, K., Bresciani, J. 1997. Parasitic infections in pond-reared rainbow trout Oncorhynchus mykiss in Denmark. Diseases of Aquatic Organisms 28: 125-138.

Buchmann, K., Lindenstrøm, T. 2002. Interactions between monogenean parasites and their fish hosts. International Journal of Parasitology 32: 309-319.

Buller, N.B. 2004. Bacteria from Fish and Other Aquatic Animals: A Practical Identification Manual. CABI Publishing, Cambridge, UK. 361 p.

Busch, S., Dalsgaard, I., Buchmann, K. 2003. Concomitant exposure of rainbow trout fry to Gyrodactylus derjavini and Flavobacterium psychrophilum: effects on infection and mortality of host. Veterinary Parasitology 117: 117-122.

Cone, D.K., Odense, P.H. 1984. Pathology of five species of Gyrodactylus Nordmann, 1832 (Monogenea). Canadian Journal of Zoology 62: 1084-1088.

Cusack, R., Cone, D.K. 1985. A report of bacterial microcolonies on the surface of Gyrodactylus (Monogenea). Fish Diseases 8: 125-127.

Cusack, R., Cone, D.K. 1986. A review of parasites as vectors of viral and bacterial diseases of fish. J Fish Diseases 9: 169-171.

Dalsgaard, I., Høi, L., Siebeling, R.J., Dalsgaard, A. 1999. Indole-positive Vibrio vulnificus isolated from disease outbreaks on a Danish eel-farm. Diseases of Aquatic Organisms 35: 187-194.

Dangel, K.C., Keppel, M., Le, T.T.Y., Grabner, D., Sures, B. 2015. Competing invaders: Performance of two Anguillicola species in Lake Bracciano. International Journal for Parasitology Parasites and Wildife 4: 119-124.

Davidsen, M. 2012. The effect of incubation temperature on embryonic development and muscle growth in yolk-sac larvae of the European eel (Anguilla anguilla L., 1758). (M.Sc. Thesis) Norwegian University of Science and Technology.

Dezfuli, B.S., Giari, L., Simoni, E., Menegatti, R., Shinn, A.P., Manera, M. 2007. Gill histopathology of cultured European sea bass, Dicentrarchus labrax (L.), infected with Diplectanum aequans (Wagener 1857) Diesing 1958 (Diplectanidae: Monogenea). Parasitology Research 100: 707713.

Easy, R.H., Ross, N.W. 2009. Changes in Atlantic salmon, Salmo salar, epidermal mucus protein composition profiles following infection with sea 
lice, Lepeophtheirus salmonis. Comparative Biochemistry and Physiology 4: 159-167.

El-Gendy, M.Y. 2007. Epizootiological studies on some bacterial infections in marine fishes. (PhDThesis) - Cairo University, Cairo, Egypt.

Elgendy, M.Y. 2013. Epizootiological and molecular studies on the common septicemic bacterial diseases of some saltwater fishes. (PhDThesis) - Cairo University, Cairo, Egypt.

Elgendy, M.Y., Moustafa M, Gaafar AY, Borhan T. 2015a. Impacts of extreme cold water conditions and some bacterial infections on earthen-pond cultured Nile tilapia, Oreochromis niloticus. RJPBCS 6: 136-145.

Elgendy, M.Y., Soliman, W.S., Hassan, H.A., Kenawy A.M., Liala A.M. 2015b. Effect of abrupt environmental deterioration on the eruption of vibriosis in mari-cultured shrimp, Penaeus indicus, in Egypt. Fisheries and Aquatic Science 10: 146158.

Estensoro, I., Jung-Schroers, V., Álvarez-Pellitero, P., Steinhagen, D., Sitjà-Bobadilla, A. 2013. Effects of Enteromyxum leei (Myxozoa) infection on gilthead sea bream, Sparus aurata (Teleostei) intestinal mucus: glycoprotein profile and bacterial adhesion. Parasitology Research 112: 567-576.

Esteve, C., Alcaide, E. 2009. Influence of diseases on the wild eel stock: the case of Albufera Lake. Aquaculture 289: 143-149.

Evans, J.J., Klesius, P.H., Pasnik, D., Shoemaker, C.A. 2007. Influence of natural Trichodina sp. parasitism on experimental Streptococcus iniae or Streptococcus agalactiae infection and survival of young channel catfish Ictalurus punctatus (Rafinesque). Aquaculture Research 38: 664-667.

FAO, 2014. The State of World Fisheries and Aquaculture. Opportunities and challenges.

Gustafson, L.L., Ellis, S.K., Bartlett, C. A. 2005. Using expert opinion to identify risk factors important to infectious salmon-anemia (ISA) outbreaks on salmon farms in Maine, USA and New Brunswick, Canada. Preventive Veterinary Medicine 70: 17-28.

Haenen, O.L., Lehmann, J., Engelsma, M.Y., Stürenberg, F.J., Roozenburg, I., Kerkhoff, S., Breteler, J. K. 2010. The health status of European silver eels, Anguilla anguilla, in the Dutch River Rhine Watershed and Lake ljsselmeer. Aquaculture 309: 15-24.

Hayward, C., Iwashita, M., Ogawa, K., Ernst, I. 2001. Global spread of the eel parasite Gyrodactylus anguillae (Monogenea). Biological Invasions 3:
$417-424$.

Jacoby, D., Gollock, M. 2014. Anguilla anguilla. The IUCN Red List of Threatened Species. Version. 3. Available at www.iucnredlist.org. <Access in: March 2015.>

Kim, M.S., Jeong, H.D. 2001. Development of 16S rRNA targeted PCR methods for detection and differentiation of Vibrio vulnificus in marine environments. Aquaculture 193: 199-211.

Madinabeitia, I., Ohtsuka, S., Okuda, J., Iwamoto, E., Yoshida, T., Furukawa, M., Nakaoka, N., Nakai, T. 2009. Homogeneity among Lactococcus garvieae isolates from striped jack, Pseudocaranx dentex (Bloch \& Schneider), and its ectoparasites. Fish Diseases 32: 901-905.

Marco-Noales, E., Milan, M., Fouz, B., Sanjuan, E., Amaro, C. 2001. Transmission to Eels, Portals of Entry, and Putative Reservoirs of Vibrio vulnificus Serovar E (Biotype 2). Applied and Environmental Microbiology 67: 4717-4725.

Mellergaard, S., Dalsgaard, I. 1987. Disease problems in Danish eel farms. Aquaculture 67: 139-146.

Montgomery, M.T., Kirchman, D.L. 1994. Induction of chitin-binding proteins during the specific attachment of the marine bacterium Vibrio harveyi to chitin. Applied and Environmental Microbiology 60: 4284-4288.

Moustafa, M., Eissa, A. E., Laila, A. M., Gaafar, A.Y., Abumourad, I.M., Elgendy, M.Y. 2015. Investigations into the Potential Causes of Mass Kills in Mari-Cultured Gilthead Sea Bream, Sparus aurata, at Northern Egypt. Research Journal of Pharmaceutical, Biological and Chemical Sciences 6: 466-477.

Moustafa, M., Eissa, A.E., Laila, A.M., Gaafar, A.Y., Abumourad, I.M.K., Elgendy, M.Y. 2014. Mass Mortalities in: Mari-Cultured European Sea Bass (Dicentrarchus labrax) at Northern Egypt. Research Journal of Pharmaceutical, Biological and Chemical Sciences 5: 95- 109.

Nielsen, T., Prouzet, P. 2008. Capture-based aquaculture of the wild European eeL, Anguilla anguilla. In A. Lovatelli and P.F. Holthus (eds). Capture-based aquaculture.Global overview. FAO, Rome, Italy. p. 141-168. (FAO Fisheries Technical Paper. No. 508).

Nylund, A., Hovland, T., Hodneland, K., Nilsen, F., Lovik, P. 1994. Mechanisms for transmission of infectious salmon anemia (ISA). Diseases of Aquatic Organisms 19: 95-100.

Nylund, A., Wallace, C., Hovland, T. 1993. The possible role of Lepeophtheirus salmonis (Krøyer) in the transmission of infectious salmon anemia. 
In: Boxshall, G.A., Defaye, D. eds. Pathogens of wild and farmed fish: sea lice. Ellis Horwood, Chichester, UK. p. 367-373

Ogawa, K., Egusa, S. 1980. Gyrodactylus infections of cultured eels (Anguilla japonica and A. anguilla) in Japan. Fish Pathology 15: 95-99.

Pylkko, P., Suomalainen, L.R., Tiirola, M., Valtonen, E.T.2006. Evidence of enhanced bacterial invasion during Diplostomum spathaceum infection in European grayling, Thymallus thymallus L. Fish Diseases 29: 79-86.

Shin, S.H., Sun, H.Y., Park, R.Y., Kim, C.M., Kim, S.Y., Rhee, J.H. 2005. Vibrio vulnificus metalloprotease VvpE has no direct effect on the iron-assimilation from human holotransferrin. FEMS Microbiology Letters 247: 221-229.

Shoemaker, C.A., XU, D., Klesius, P.H., Evans, J.J. 2008. Concurrent infections (Parasitism and bacterial disease) in Tilapia. Proceedings of the 8th International Symposium on Talipia in Aquaculture Cairo, Egypt. pp. 1365-1375.

Wright, A.C., Morris, J.G. 1991. The extracellular cytolysin of Vibrio vulnificus: inactivation and relationship to virulence in mice. Infect Immunity 59: 192-197.

Xu. D., Shoemaker, C.A., Klesius, P.H. 2007. Evaluation of the link between gyrodactylosis and streptococcosis of Nile tilapia, Oreochromis niloticus (L.). Fish Diseases 30: 233-238. 